\title{
Green Industrial System in Indonesia
}

\author{
Fourry Handoko ${ }^{1, *}$, Ellysa Nursanti $^{1}$, Gatot ${ }^{1}$, Martinus Edwin Tjahjadi ${ }^{2}$, Julianus Hutabarat ${ }^{1}$, Lalu Mulyadi ${ }^{3}$, and \\ Kustamar $^{4}$ \\ ${ }^{1}$ Industrial Engineering Department, National Institute of Technology (ITN), Jl. Raya Karanglo Km. 2, \\ Malang, 65145, Indonesia \\ ${ }^{2}$ Geomatics Engineering Department, National Institute of Technology (ITN), Jl. Bendungan Sigura-gura No.2, \\ Malang, 65145, Indonesia \\ ${ }^{3}$ Architecture Engineering Department, National Institute of Technology (ITN), Jl. Bendungan Sigura-gura No.2, \\ Malang, 65145, Indonesia \\ ${ }^{4}$ Civil Engineering Department, National Institute of Technology (ITN), Jl. Bendungan Sigura-gura No.2, \\ Malang, 65145, Indonesia
}

\begin{abstract}
The environmentally friendly manufacturing influences the worldwide community both private and public to run the concept of green productivity. The concept of green productivity drives the organisation to seek integration of sustainable environmental management and environmentally friendly production system design. The lack of green and sustainable concept have reduced the competitiveness of the organisation due to the low capability to meet the international standard of ISO 14000 . One of the important thing of being 'green' is our capability to deal with the pollution. Continuous improvement approach to achieve green productivity is an effort to increase sustainable competitiveness by maintaining green product and reducing the pollution. The continuous improvement to achieve the capability to overcome the pollution problem will lead into tangible and intangible benefit. It is therefore the green productivity is crucial. In this research, the concept of green produtivity and continuous improvement approah are utilised to overcome the problems of pollution in manufacturing industries.
\end{abstract}

Key words: Continuous improvement, green industrial system, policy, production

\section{Introduction}

Numerous organisations worldwide have been involved in green environment programs. Regulation and ratification of environmentally friendly product have been constructed by both develop and developing countries [1]. The growing awareness of international communities about environmentally friendly product and also 'save our earth' jargon has been elevating the imperative of the pollution free environment programs [2, 3], since our environment has suffered from un-controlled and massive exploitation of natural resources; indecomposable waste; and environmental pollution, resulting significant damage such as environmental degradation, global warming and ozone hole [4, 5].

In response, the government, businesses and universities began to campaign for environmentally friendly and energy saving products approach $[2,4,6-10]$. This approach is imperative since the capability of the organisation to deal with the environmental issues have been considered as a mean to improve organisation's competitiveness in both regional and international business environment. Furthermore, the current international policies have been maintaining the issues of the environment friendly product through the international standard series of ISO 14000 certification and other ecolabelling programs [11-15]. The Indonesian government has also initiated programs of green environment in the form of cleaner production programs [14], but this program has not been well delivered to business owners in Indonesia. To response for this issue, this study is needed to discover the implementation of green productivity in Indonesia. This study was conducted to find the way of implementation green industrial system in manufacturing industries.

\footnotetext{
*Corresponding author: fourry@lecturer.itn.ac.id
} 


\section{Green productivity}

The application of Green Productivity through non-product output (NPO) is the appropriate technique, technology, and management system to produce environmentally friendly products and services [16]. Green Productivity (GP) uses the concept of environmentally friendly production yet minimum energy without disturbing productivity or also known as green industry. This environmentally friendly and energy efficient approach influences the worldwide community both private and public. GP is a concept that involves management decision, environmental programs and technologies that lead to environmentally friendly product [1,15-18]. The concept of green productivity drives the organisation to seek integration of sustainable environmental management and environmentally friendly production system design. Continuous improvement to achieve GP is an effort to increase sustainable competitiveness by maintaining green product and reducing the pollution [16].

\subsection{GP as a competitive strategy}

Organisations worldwide are under regulatory pressure to be eco-efficient [19]. Therefore, the competitive strategy trough continuous improvement is a must. GP approach should be applied to achieve the competitiveness goal. Validation regarding tools and techniques application of GP is a part of organisation's continuous improvement efforts to get green product. The responsibility of the GP taskforce is to provide tools and technologies for implementing 'green' programs, including reduce, reuse and recycle (3R)[18]; and also internal audit for green, and implementing continuous improvement program (Plan, Do, Check and Action) GP to achieve sustainable competitiveness, from product design up-to final product stage $[8,20]$.

\section{Methodology}

This study identified the factors that could interfere the GP, and provide suggestions for improvement based on the external and internal regulations such as ISO 14000 and government regulation. Cause and effect approach were applied to seek the gap between available process and the regulation, followed by Quality Function Deployment (QFD) approach to determine the improvement needed. However, in conducting the research, it was necessary to resolve several issues that potentially disturb the result of the research. These included: determine the research domain, level of analysis and selecting suitable respondents.

\subsection{Research domain}

The subject of the research was a chemical company in East Java, Indonesia. This domain was chosen based on its potential role in GP practices, especially in reducing pollution. This company significantly applied GP approach. As this organisation has a strong commitment in GP approach and also developed knowledge regarding environmentally friendly product, the organisation was deemed as appropriate subject of this study.

\subsection{Level of analysis}

The issue related to the level of analysis was the persons in the organisation who were directly selected as a respondent. Ideally, the questionnaires should be completed by number of people in each part of an organisation. This approach was applied to obtain the sufficient information from the organisations, and to minimise the response bias of the respondents [21-26]. In this survey, people who were selected to be respondents were the employees whom are responsible (incharge) for the GP program of the organisation.

\subsection{Sample selection}

For data sampling, more than 30 respondents were selected. The respondents were checked to ensure that respondents only belong to departments, which were responsible for GP program.

\subsection{Research sequences}

The research consists of four phases. The details are presented as follows: 
Phase I: Assessment of instrument for green approach. This phase involved the preliminary studies; literature and regulations review. Reviewing includes the review on the Green Standard of ISO 14001, Decree No. 3 Year 2006 about 'Green Indonesia' and regulation of the Minister of Environment no. 18 year 2010 about program of companies rating performance (PROPER). The purpose of this phase was to collect information and data to construct the instruments that will be applied to assess GP based on the selected criteria of ISO 14000 clauses and government regulation. The instruments then were distributed to 33 respondents.

Table 1. ISO 14001 clauses.

\begin{tabular}{|l|l|}
\hline Clause & Audit Clause \\
\hline 4.2 & Environmental policy \\
\hline 4.3 .1 & Identification of environmental aspects and impacts \\
\hline 4.3 .2 & Identification of legal regulations and other requirements \\
\hline 4.3 .3 & Objectives, targets and programs \\
\hline 4.4 .1 & Resources, roles, responsibility and authority \\
\hline 4.4 .2 & Training, awareness, competence \\
\hline 4.4 .3 & Communication \\
\hline 4.4 .4 & Documentation \\
\hline 4.4 .5 & Control of documents \\
\hline \multirow{2}{*}{4.4 .6} & $\begin{array}{l}\text { Operational control; Purchasing; Handling, Storage, Packaging, } \\
\text { Delivery; Environmental control }\end{array}$ \\
\hline 4.4 .7 & Preparing and emergency response \\
\hline 4.5 .1 & Monitoring and measurement \\
\hline 4.5 .2 & Evaluation of conformity \\
\hline \multirow{3}{*}{4.5 .3} & Nonconformity, corrective action, and preventive \\
\cline { 2 - 2 } & Corrective Action \\
\cline { 2 - 2 } & Precautions \\
\hline 4.5 .4 & Control of records \\
\hline 4.5 .5 & Internal environmental audits \\
\hline 4.6 & Overview of management \\
\hline
\end{tabular}

Phase II: Assessment. At this phase, the activity of the business process of the organisation and the information process associated with the activities of the GP were recorded. The area of production process control was selected to be a subject of this research. The area was chosen because this department has a significant role in controlling the pollutant. The assessment of the level of adoption of GP in that area was conducted based on the instruments of ISO 14001 clauses that have been constructed in the previous stage. Assessment phase aims to determine the remaining gap/problem between the application of GP and the ISO 14000 clauses. Based on the assessment result, the current position of the GP application was analysed to find the main factors that produce the gap/problem.

Phase III: Identification of gap/problem. This third phase was to review the main causes of the gap/problem between the implementation of GP and ISO 14000 clauses. The findings of the gap/problems were tabulated. The cause and effect diagram then was applied to identify the root of the problems. The brainstorming technique was utilise to analyse the problem based on 4M (Man Machine, Method dan material) approach. The main causes of the problem and then transformed into GP standard.

Phase IV: Strategy development. The fourth phase aimed to provide alternative solutions regarding the causes of the problems of the gap. Brainstorming and Quality Function Deployment (QFD) were applied to obtain the proposed solution for the company improvement of GP. QFD is a tool to design and develop methods.

QFD is capable in diffusing the quality into a design. In this study, new policies to improve GP were translated into a technical response. By QFD, The assessment results form previous phase were summarised into a house of quality matrix, containing the matrix relationship, technical correlation, and technical matrix. Prior to the strategy development, QFD approach was applied to produce questionnaires for respondents. The 33 respondents were selected. Questionnaires distribution was conducted carefully to meet the adequacy of the data, validity and reliability. The results of the questionnaires were utilised as attributes to assess whether GP standard in the organisation meets the ISO 14000 clauses or not. The results were also employed to determine the particular part of the GP application in production process that needs improvement. So the organisation could develop the future strategy of GP. 


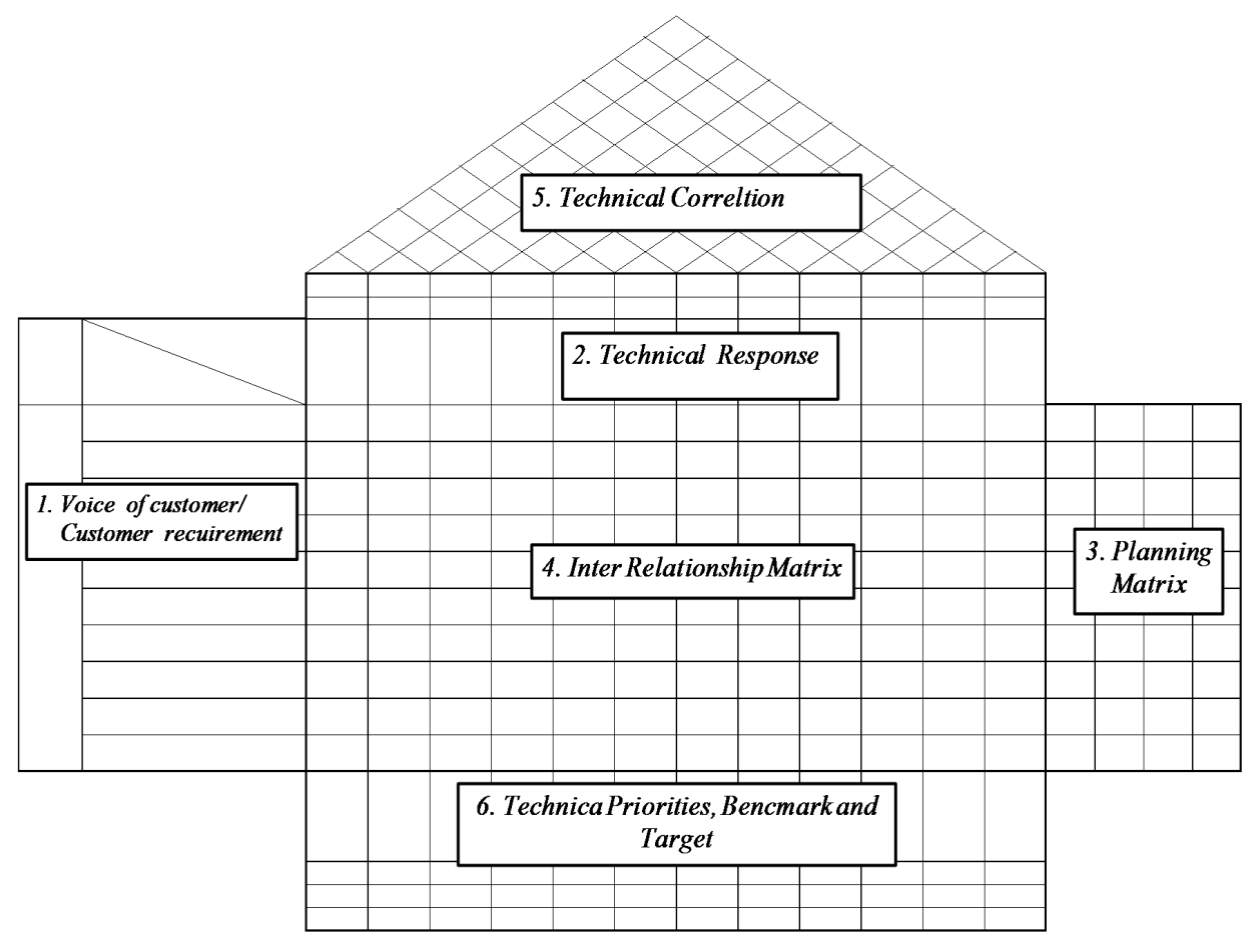

Fig. 1. House of quality (HoQ).

\section{Results and discussion}

Reliability and validity tests were conducted to verify the reliability and validity of the instruments.

\subsection{Reliability and validity test}

Before validity test, the test of the adequacy of the data was performed based on the formula [26]. If the specified confidence interval (CI) of $95 \%$ the value of $Z=1.645$. While the error of $5 \%, \sigma 2=0.891$ then the minimum number of samples needed are 32 respondents. The numbers of questionnaires distributed were 40, and the responses are up to 33 respondents. Nevertheless, the number of respondents meets the minimum requirement $(33$ respondents $>32$ respondents). Statistical measurement was conducted to test the reliability and validity of the measurement instrument. Pearson correlation and Cronbach's alpha coefficient were applied to measure the validity and reliability of the instrument. This approach was taken to ensure that the measurement instrument was capable of measuring what was intended to be measured. For all items, Cronbach's alpha coefficient values were greater than the acceptable value of 0.6 [24-26], indicating that the items assigned to the constructs were reliable.

\subsection{Assessment result based on the ISO 14000 clauses requirement}

The target score of the assessment is between 155 and 165 that indicates a good score. The assessment results of the GP application based on the ISO 14000 requirement, the lowest score was 151 (Clause 4.4 .6 (ISO 14000) operation control). The result indicates that the application of GP is still unacceptable.

The descriptions of operation control clauses are as follows:

Operational Control clause ISO 14000, question no. 45. 'Does the company have a method to ensure the activities, services, or products that may have an impact on the environment has been adequately controlled?' (Score: 149). Question 45: Whether the procedure has been covering all the activities of the company, since the beginning of the raw material or other additional material up to the utilised of those raw material delivered from the company? (Score: 153). Based on the data evaluation using the assessment instruments it was discovered that the green productivity deficiencies 
control is associated with ISO 14000 clause 4.4.6 about operation control question no. 45, especially in the treatment process.

Based on the assessment results, "the lack of method regarding to ISO 14000 clause 4.4.6 about operation control question no. 45', particularly regarding to waste treatment method/procedure, the evaluation to find the gap was conducted using cause and effect (Fishbone) diagram. The results of the identification of causes variables the failure of waste treatment using fishbone diagrams and brainstorming are presented as follows:

(i) No suitable method

(ii) No measurement standard

(iii) No method improvement

(iv) Inappropriate waste treatment unit (WTU)

(v) Hazardous chemical for bacteria in WTU

Using fishbone diagrams and brainstorming technique, the causes variables were analysed to obtain the attribute of production operation control. The attributes were the representative of customer needs. There were 19 attributes. The attributes and then were translated into 19 technical responses (TRs) scheme and seek the problem solving to achieve GP strategies by using QFD.

The 19 attributes TRs were put into the planning matrix of HoQ. The matrix of HoQ transformed the attributes into survey instruments that were distributed to get the respond from the respondents. The respondents were asked to determine the priority for the future improvement from the available list of the attributes, based on Improvement ratio, interest level (Improvement ratio and interest level were obtained to determine the raw weight). The result shows that the highest weighted of technical response from the attributes are instrument 16 (Equipment to reduce odor), 17 (methods to prevent odor) and 18 (monitoring for water pollution).

Based on that result, the solution was implemented with PDCA method by simultaneously installing the new equipment and arranging the particular method to overcome the odor pollution. Further, the monitoring was conducted to guarantee that the problem solving is consistently conducted. The waste-processing unit to eliminate the cause of odor originating from ammonia by building the Stripping Ammonia unit PDCA is presented in Table 2.

Table 2. PDCA implementation.

\begin{tabular}{|l|l|l|}
\hline Plan & Check & Action \\
\hline Reduce Nitrogen with new equipment & Nitrogen content reduction $\leq 50 \%$ & Optimisation \\
\hline Do & Task force & \\
\hline $\begin{array}{l}\text { i.Splitting the waste with high loading } \\
\text { ammonia }\end{array}$ & WWT and refinery & \\
i. Installation of ammonia Stripping \\
$\begin{array}{l}\text { Equipment } \\
\text { ii. Splitting between Low ammonia and High } \\
\text { ammonia in waste treatment installation }\end{array}$ & Engineering and Refinery & \\
& Refinery and WWT & \\
\hline
\end{tabular}

The principle of ammonia stripping is to drive the ammonia into the evaporated effluent and then be condensed. The result of the condensation can be utilised as elusion washing at the ionic separation stage of ammonia (using NH3 $0.8 \mathrm{~N}$ ). The (before and after) tests of the impact of Ammonia Stripping Installation were conducted. The result is presented below.

Table 3. Before and after tests result

\begin{tabular}{|l|l|l|l|}
\hline Parameter & Unit & Before & After \\
\hline BOD (Biochemical Oxygen Demand) & $\mathrm{uL} \mathrm{L}^{-1}$ & 77 & 75 \\
\hline COD (Chemical Oxygen Demand) & $\mathrm{uL} \mathrm{L}^{-1}$ & 134 & 121 \\
\hline NH3 (ammonia) & $\mathrm{uL} \mathrm{L}^{-1}$ & 298 & 105 \\
\hline
\end{tabular}

The installation of the ammonia stripping has impacted significantly on the GP improvement. By Two samples t-test the $\mathrm{P}$-value $=0.000$ indicates significant $(\mathrm{P}<0.05$ significant $)$.

Table 4. Two-Sample t-test and CI.

\begin{tabular}{|l|l|l|l|l|}
\hline \multicolumn{5}{|c|}{ Two-sample t-test for data AN } \\
\hline Subject & N & Mean & SD & SE Mean \\
\hline 1 & 19 & 299.7 & 48.6 & 11 \\
\hline 2 & 28 & 104.9 & 17.4 & 3.3 \\
\hline
\end{tabular}


Difference $=\mathrm{mu}(1)-\mathrm{mu}(2)$, Estimate for difference: 194.797

$95 \%$ CI for difference: $(174.705 ; 214.889)$

t-test of difference $=0$

$\mathrm{t}$-value $=19.53 ; \mathrm{P}-$ Value $=0.000 ; \mathrm{DF}=45$

Both use Pooled StDev $=33.5624$

Table 5. Investment cost and benefit.

\begin{tabular}{|l|l|l|l|l|}
\hline Name & Unit & Need & Price (USD) & (USD)/yr \\
\hline Steam/h & $\mathrm{t}$ & 6.1 & 15.94 & 851769.84 \\
\hline Electricity & $\mathrm{Kw} \mathrm{h}$ & 22 & 0.062 & 11948.64 \\
\hline Cooling water/h & $\mathrm{kL}$ & 80 & 0.02 & 14016 \\
\hline $\begin{array}{l}\text { Investment/ } \\
\text { fixed cost }\end{array}$ & $\mathrm{USD}$ & 400.000 & 400.000 & 452000 \\
\hline Total investment & & & & 1329734.48 \\
\hline $\begin{array}{l}\text { Ammonia } \\
\text { recovery } \\
\text { benefit/d }\end{array}$ & $\mathrm{t}$ & 4.984 & 686 & 3419024 \\
\hline
\end{tabular}

Table 5 shows that the ammonia recovery also gives a significant financial benefit. The Break Event Point (BEP) of the investment is about 5 mo.

\subsection{Continuous improvement}

The learning process will sharp the capability to solve the problem [27-29]. The capability improvement will ease the process of continuous improvement. Based on the direction of the QFD solution, the management, monitoring and treatment plant improvement to eliminate the problem were upgraded. The recommendation, as a result of the QFD to overcome the problems, was implemented. After the implementation of treatment plant, the analysis to find the effect of before and after was conducted. The result was applied as a standard for upcoming improvements. The result shows a significant improvement, especially the decrease of up to $65 \%$ of the pollutant.

\section{Conclusion}

This research was conducted through theoretical and empirical studies to review the variables and attributes that can be developed as a strategy to deal with the waste in department of production. The application of continuous improvement is capable of locating, measuring, and overcoming the gaps/problems regarding green productivity application. This method delivers a comprehensive improvement in green-based production process application. The finding shows that even the respondents' organisation has recognised the green-based production process particularly in production division, but there are still some gaps/problems that could be found. These deficiencies regarding the GP can be overcome with the improvement of a strategy, tool, checking, monitoring and supervision to prevent pollution based on the recommendation that involve the employees that involve in that area. The application of the continuous improvement leads the decrease of environment pollutants up to $65 \%$ pollutant. The ammonia recovery also gives a significant financial benefit. The Break Event Point (BEP) of the investment is about 5 months.

\section{References}

1. O. Boiral. Organ. Sci. 18:127-146 (2007). https://pubsonline.informs.org/doi/abs/10.1287/orsc.1060.0224

2. T.B. Chen, L.T. Chai. Journal of Management Science and Engineering, 4(2):27-39 (2010). http://cscanada.net/index.php/mse/article/view/j.mse.1913035X20100402.002

3. J. Dedrick. Communications of the Association for Information Systems, 27(11):173-184 (2010). http://citeseerx.ist.psu.edu/viewdoc/download?doi=10.1.1.186.7721\&rep=rep1\&type=pdf

4. P.K. Ip. J. Bus. Ethics 88(1):211-224 (2009). https://link.springer.com/article/10.1007/s10551-008-9820-2

5. C.Y. Lin, Y.H. Ho. J. Bus. Ethics 98(1):67-83 (2011). https://link.springer.com/article/10.1007/s10551-010-0535-9

6. F. Handoko, IJPTE, 1(2):93-107 (2017). https://jurnal.uns.ac.id/ijpte/article/view/15124/12410

7. S. Brammer, H. Walker. IJOPM, 31(4):452-476 (2011). http://www.emeraldinsight.com/doi/abs/10.1108/01443571111119551

8. A.M. Deif. APEM. 6(1):27-36 (2011). http://apem-journal.org/Archives/2011/APEM6-1 027-036.pdf

9. D. Etzion. J. Manag. 33(4):637-664 (2007). http://journals.sagepub.com/doi/abs/10.1177/0149206307302553

10. J. Liu, H. Viney, D. Holt. European Business Journal 16(2)59-69 (2004). http://oro.open.ac.uk/1898/ 
11. R.B. Clements. Complete guide to ISO 14000. Upper Saddle River: Prentice Hall (1996). pp. 78-95. https://www.amazon.com/Complete-Guide-Richard-Barrett-Clements/dp/0132429756

12. F. Wiengarten, M. Pagell, B. Fynes. J. Clean. Prod. 56:18-28 (2012). https://www.sciencedirect.com/science/article/pii/S0959652612000339

13. Q. Wang, F. Lai, X. Zhao. Supply Chain Management: An International Journal, 13(2):138-150 (2008). http://www.emeraldinsight.com/doi/abs/10.1108/13598540810860976

14. Ministry of Environmental. Peraturan menteri negara lingkungan hidup nomor 31 tahun 2009. [The ministry of environmental decree no.31, 2009]. Jakarta: Ministry of Environmental (2009). [in Bahasa Indonesia]. http://puupi.menlh.go.id/pdf/ind/IND-PUU-7-2009-Permen\%20No.\%2031Thn\%202009-Ekolabel\%20Stantek.pdf

15. UNEP. Emerging issues in our global environment. United Nation: UNEP Year Book (2011). pp. 33-38. http://wedocs.unep.org/handle/20.500.11822/8276? show=full

16. H. Widyantoro, F. Handoko, E. Nursanti. Pengendalian biaya manufaktur berbasis environment oriented costmanagement (EOCM). [Manufacturing cost control based on environment oriented costmanagement (EOCM)]. SENIATI (Malang, Indonesia, 2016). [in Bahasa Indonesia]. http://ejournal.itn.ac.id/index.php/seniati/article/view/107/100

17. M. Atlas, R. Florida, Green manufacturing. In: Handbook of technology management. R.C Dorf (Ed.). America: CRC Press. (1998). pp. 25-33.

https://books.google.co.id/books?id=C2u8I0DFo4IC\&dq=M.+Atlas, +R.+Florida. + Handbook + of + Technology + Man agement\&source $=$ gbs navlinks $\mathrm{s}$

18. C. Paula, F. Handoko, Implementasi reduce, reuse, recycle (3R) untuk memenuhi kebutuhan palet pada PT. X. [Implementation Reduce, Reuse, Recycle (3R) to Meet the Needs Palette at PT. X]. SENIATI (Malang, 2016). [in Bahasa Indonesia]. http://ejournal.itn.ac.id/index.php/seniati/article/view/97/90

19. W. R. Scholz, A. Wiek. J. Ind. Ecol. 9(4):155-170 (2005). http://onlinelibrary.wiley.com/doi/10.1162/108819805775247963/abstract

20. K.D. Kalla, A. Brown. Infusing a sustainable green manufacturing course into manufacturing/mechanical engineering technology program. Washington DC: American Society for Engineering Education (2012). https://www.google.co.id/url?sa=t\&rct=j\&q=\&esrc=s\&source=web\&cd=1\&cad=rja\&uact=8\&ved=0ahUKEwjPtbue mtrYAhUKI5QKHcpJBJ8QFggoMAA\&url=http $\% 3 \mathrm{~A} \% 2 \mathrm{~F} \% 2 \mathrm{Fwww}$.asee.org\%2Fpublic $\% 2 \mathrm{Fconferences} \% 2 \mathrm{~F} 8 \% 2 \mathrm{~F}$ papers\%2F5384\%2Fdownload\&usg=AOvVaw05mI7xTiGekGtp7hYGhDqm

21. P.J. Singh, A.J.R. Smith. Journal of Manufacturing Technology Management, 15(5):394-401 (2004). https://www.scopus.com/record/display.uri?eid=2-s2.0-4143087474\&origin=resultslist\&sort=plf-

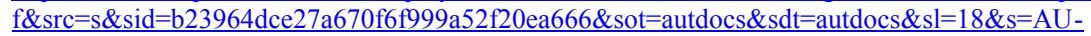
$\underline{\mathrm{ID} \% 2855498580900 \% 29 \& \text { relpos }=17 \& \text { citeCnt }=87 \& \text { searchTerm }=}$

22. B.B. Flyn, R.G. Shroeder, S. Sakakibara. Journal of Operations Management, 11(4):339-366 (1994). https://www.sciencedirect.com/science/article/pii/S0272696397900048

23. P.J. Singh. A study of theoretical and empirical bases of operationalising popular quality management approaches in manufacturing organizations in Australia. [Thesis]. University of Melbourne, Australia (2002).

https://www.researchgate.net/publication/260908699_A_Study_of_Theoretical_and_Empirical_Bases_of_Operation alising_Popular_Quality_Management_Approaches_in_Manufacturing_Organizations in_Australia

24. J.F. Hair Jr, W.C. Black, B.J. Babin, R. E. Anderson. Multivariate data analysis. (7 ed.). New Jersey: Prentice-Hall. (2014). https://www.amazon.com/Multivariate-Data-Analysis-Joseph-Hair/dp/0138132631

25. F. Handoko, A. Smith, C. Burvill. JCEBS, 12(2):171-180 (2014). http://www.tandfonline.com/doi/abs/10.1080/14765284.2014.900968

26. F. Handoko, E. Nursanti, D. Harmanto, Sutriyono, ARPN JEAS, 11(8):5275-5282 (2016). http://www.arpnjournals.org/jeas/research_papers/rp_2016/jeas_0416 4105.pdf

27. M.E. Tjahjadi, F. Handoko, S.S. Sai. IJECE, 7(3):1188-1196 (2017). http://iaesjournal.com/online/index.php/IJECE/article/view/14794

28. S. Mahanal, S. Zubaidah, A. Bahri, M.S. Dinnurriya. Asia-Pacific Forum on Science Learning and Teaching, 17(2): art. no. 21 (2016). https://eric.ed.gov/?q=thinking+skills\&id=EJ1145728

29. B.A. Prayitno, D. Corebima, H. Zubaidah, M. Ramli. JBSE, 16(2):266-277 (2007). http://www.scientiasocialis.lt/jbse/?q=node/564 